Check for updates

Cite this: RSC Adv., 2019, 9, 36690

\title{
5-Acetamido-1-(methoxybenzyl) isatin inhibits tumor cell proliferation, migration, and angiogenesis $\dagger$
}

\author{
Qian Zhang,,$^{\text {t }}$ Ying Fu,,$^{\text {a }}$ Yufan Zhao, ${ }^{a}$ Shanshan Cui, ${ }^{a}$ Jing Wang, ${ }^{a}$ Fengxi Liu, ${ }^{a}$ \\ Yuan Yuan, ${ }^{a}$ Hervé Galons, *ab Peng Yu*a and Yuou Teng (iD) *a
}

Indole and its derivatives are widely distributed in both animals and plants. Among its array of biological activities, the anti-tumor activity of indole has garnered much attention. Furthermore, the synthesis and activity of indole derivatives, including isatin, constitute a flourishing research topic. Previously, many isatin derivatives were synthesized by our group, and 5-acetamido-1-(methoxybenzyl) isatin was screened as a candidate anti-tumor agent. In this study, we found that 5-acetamido-1-(methoxybenzyl) isatin inhibited the proliferation of several tumor cell lines, especially the human leukemia cell line K562. Morphological observation suggested that 5-acetamido-1-(methoxybenzyl) isatin induced apoptosis and caused cell cycle arrest in K562 cells. Flow cytometry revealed that 5-acetamido-1-(methoxybenzyl) isatin induced mitochondrial pathway-mediated apoptosis in K562 cells. Moreover, it downregulated Cyclin B and CDC25C and upregulated p-CDC25C and p-CDK1 (Thr14), and induced K562 cell cycle arrest in the $G_{2} / M$ phase. Findings from wound healing as well as transwell assay determined that 5acetamido-1-(methoxybenzyl) isatin could suppress migration and chemotaxis in HepG2 liver cancer cells. 5-Acetamido-1-(methoxybenzyl) isatin also inhibited angiogenesis of the human umbilical vein endothelial cell line HUVEC, determined via a cell tube formation study. A clone formation study indicated that 5-acetamido-1-(methoxybenzyl) isatin can inhibit tumor cell proliferation and population dependence in a concentration-dependent manner. Thus, our findings support that 5-acetamido-1(methoxybenzyl) isatin could be used as a potential antitumor candidate in future investigations.

Received 2nd September 2019 Accepted 31st October 2019

DOI: 10.1039/c9ra07002h

rsc.li/rsc-advances
Sunitinib involve multiple organs and systems in the body and have serious adverse reactions leading to death. ${ }^{11}$

Some antitumor drugs on the market have poor selectivity and strong cytotoxicity so that target cells develop resistance. Therefore, new types of high-efficiency anti-tumor drugs are urgently needed. 5-Acetamido-1-(methoxybenzyl) isatin (CAS registry number is 1561006-90-3) was designed as a potential anti-tumor agent by our laboratory and was screened from a series of 1,5-disubstitued isatin derivatives. ${ }^{12}$ The cytotoxic effect of 5-acetamido-1-(methoxybenzyl) isatin on multiple cancer cell lines and normal cells investigated the efficacy of 5acetamido-1-(methoxybenzyl) isatin in vitro.

Caspases are a family of proteases and important regulators of apoptosis. Caspase-3 can increase the response intensity of Caspase-8 and Caspase-9, leading to complete suicide disintegration of cells. Cleavage of PARP can be caused by Caspase-3 activation during apoptosis, a key indicator enzyme of apoptosis. Though acting on the mitochondrial membrane and collapse of the mitochondrial membrane potential, Bcl-2 family proteins play an important role in apoptosis. ${ }^{13,14}$ In terms of mitochondrial apoptotic pathway regulation, Bcl-2 family proteins are crucial and include pro-apoptotic and antiapoptotic proteins, ${ }^{15}$ which together affect cell proliferation 
and apoptosis. ${ }^{16}$ In this study, we examined the effect of 5acetamido-1-(methoxybenzyl) isatin on the expression of these apoptosis-related proteins in cancer cells.

CyclinB1 was the first discovered cyclin, synthesized in the $\mathrm{S}$ phase and expressed in the $\mathrm{G}_{2} / \mathbf{M}$ phases. ${ }^{17}$ Its translation has been demonstrated to be critical for $\mathrm{G}_{2} / \mathrm{M}$ transition of the cell cycle. ${ }^{18}$ Abnormal expression of CyclinB1 is associated with tumor invasion, metastasis, and poor prognosis. CDK1 is a CDK family member and is active in many tumors. CyclinB1 and CDK1 begin to bind in the $S / G_{2}$ phase, and $C D K 1$ kinase activity appears. The CDC25 family (CDC25A, CDC25B and CDC25C) includes phosphatases that regulate the CDK complex and cell cycle progression. When in the M phase of the cell cycle, CDC25C enters the nucleus, catalyzes CDK1 dephosphorylation at Thr14/ Tyr15, and activates the CDK1/CyclinB1 complex. But if CDC25C is abnormally expressed, dephosphorylation CDK1 at Thr14 and Tyr15 will be depressed in mitosis and the $\mathrm{G}_{2} / \mathrm{M}$ phase transition. Here, we examined the effect of 5-acetamido-1-(methoxybenzyl) isatin on the cell cycle distribution of cancer cells and on the expression of the relevant cell cycle regulatory proteins.

We also evaluated the effect of 5-acetamido-1-(methoxybenzyl) isatin on HepG2 cells and HUVECs by the wound healing assay, the transwell assay and the tube forming assay. The wound healing assay can determine the migration and repair capacity of cells. It is easy to operate, cheap, and initial developed experiment for evaluating directional migration in vitro. ${ }^{19}$ The transwell assay determines the cytotaxis, cell migration, and cell invasion capacities of cells. ${ }^{20,21}$ For the development and metastasis of tumor tissues, angiogenesis is the key. In that case, inhibiting angiogenesis is essential for the spread and deterioration of tumors. ${ }^{22}$ Using these assays, we examined the potential of 5acetamido-1-(methoxybenzyl) isatin to be used as an effective anti-tumor agent in multiple aspects.

\section{Materials and methods}

\section{Chemicals and cell culture}

The isatin was the core structure of our drug design and 5acetamido-1-(methoxybenzyl) isatin was synthesized in our laboratory. The structure of 5-acetamido-1-(methoxybenzyl) isatin is shown in Fig. 1A. The human leukemia cell line $\mathrm{K} 562$ and the human hepatic stellate cell line L-02 were purchased from Shanghai Cell Bank of Chinese Academy of Sciences (Shanghai, China) and cultured in RPMI-1640 supplemented with $10 \%$ fetal bovine serum, $2.05 \mathrm{mmol}$-glutamine and $1 \%$ penicillin/streptomycin. The human umbilical vein endothelial cell line HUVEC was purchased from ATCC (American Type Culture Collection, USA) and maintained in Ham's F-12 medium supplemented with $10 \%$ fetal bovine serum, $2.05 \mathrm{mmol}$ L-glutamine and $1 \%$ penicillin/streptomycin. The human colon cancer cell line HT-29, the human prostate cancer cell line PC-3, the liver cancer cell line HepG2, the non-small cell lung cancer cell line NCI-H460, the human breast cancer cell line MCF-7 and the human embryonic kidney cell line HEK-293 were stored in the Department of Drug Design and Synthesis, Tianjin University of Science and Technology. HepG2 cells were preserved in Dulbecco's Modified Eagle Medium (DMEM)

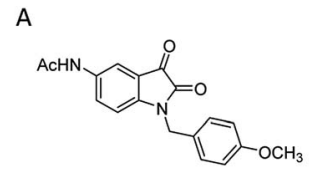

5-Acetamido-1-(methoxybenzyl) isatin

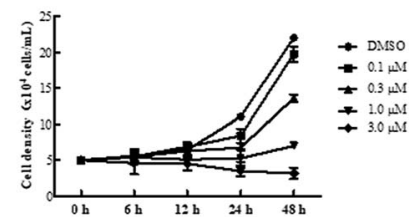

B 5-Acetamido-1-(methoxybenzyl) isatin $1 \mu \mathrm{M}$

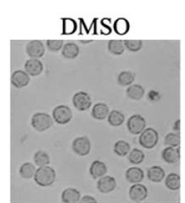
$1 \mathrm{~h}$

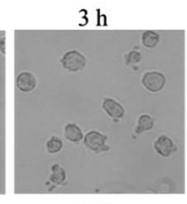
$6 \mathrm{~h}$

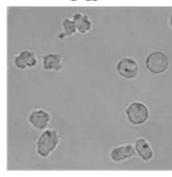

$24 \mathrm{~h}$
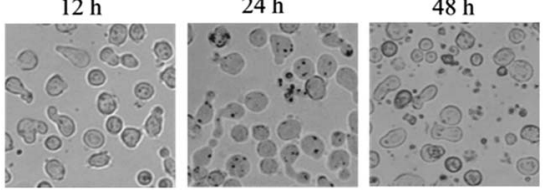

Fig. 1 Morphological changes in 5-acetamido-1-(methoxybenzyl) isatin-treated $\mathrm{K} 562$ cells. (A) Structure and in vitro anti-cell proliferative effect of 5-acetamido-1-(methoxybenzyl) isatin. (B) Morphological changes induced by 5-acetamido-1-(methoxybenzyl) isatin treatment $(1 \mu \mathrm{M})$.

supplemented with $10 \%$ fetal bovine serum, $2.05 \mathrm{mM}$ glutamine and $1 \%$ penicillin/streptomycin. All cell lines were incubated at $37{ }^{\circ} \mathrm{C}$ in a humidified incubator containing with $5 \%$ $\mathrm{CO}_{2}$ and 2-3 days should be replaced fresh complete medium.

\section{Cell proliferation assay}

The cell lines were taken in logarithmic growth phase and plated in 96-well culture plates at a density of $5 \times 10^{4}$ cells per $\mathrm{mL}$. Then, cells were incubated for a while (suspended cells for $2 \mathrm{~h}$ and adherent cells for $24 \mathrm{~h}$ ). After the incubation, different concentrations of 5-acetamido-1-(methoxybenzyl) isatin were added to per hole of the culture plates and incubated for $48 \mathrm{~h}$. Cells were incubated for another $4 \mathrm{~h}$ after $48 \mathrm{~h}$ incubation with $5 \mathrm{mg} \mathrm{mL}{ }^{-1}$ MTT $(20 \mu \mathrm{L})$. Then, adherent cells were treated carefully by removing cell culture mediums and adding $100 \mu \mathrm{L}$ DMSO per well to dissolved the formazan precipitate, suspension cells were treated by adding $100 \mu \mathrm{L}$ of isopropyl hydrochloride solution into each well and mixing. MTT assay was performed using thermo microplate reader and the inhibitory concentrations $\left(\mathrm{IC}_{50}\right)$ were calculated from dose-response curves of three independent assay.

\section{Observation of cell morphology}

K562 cells were cultured in 6-well plates with a density of $5 \times$ $10^{4}$ cells per $\mathrm{mL}$ and incubated for $2 \mathrm{~h}$ at $37^{\circ} \mathrm{C}$ in a humidified incubator containing with $5 \% \mathrm{CO}_{2}$. Then, cells were treated with $1 \mu \mathrm{M}$ 5-acetamido-1-(methoxybenzyl) isatin for 1, 3, 6, 12, $24,48 \mathrm{~h}$ and visualized by optical microscope at the corresponding time.

\section{Quantification apoptosis by flow cytometry}

The extent of apoptotic cells were monitored by the Annexin-VFITC Apoptosis Detection Kit (Tianjin Sungene Biotech Co., 
Ltd.) on the basis of the manufacturer's instructions. K562 cells $\left(5 \times 10^{4}\right.$ cells per $\left.\mathrm{mL}\right)$ were treated with DMSO or 5-acetamido1-(methoxybenzyl) isatin $(1 \mu \mathrm{M})$ for $0,6,12,24$ and $48 \mathrm{~h}$ respectively. After the exposure, cells were collected, washed with PBS at $461 \mathrm{~g}$ and gently resuspended in $1 \times$ binding buffer. Then, the cells were incubated with Annexin-V-FITC (Annexin VFluorescein isothiocyanate) and PI (propidium iodide) for $10 \mathrm{~min}$ in dark at room temperature and evaluated by flow cytometry. Subsequently, quadrant statistics was used to analyze the fraction of cell population in different quadrants.

\section{Measurement of mitochondrial membrane potential}

Mitochondria are the key subcellular organelles for many anticancer drugs to induce apoptosis and the loss of mitochondrial membrane potential is a major factor in the mitochondrial induced apoptosis pathway. ${ }^{23}$ To detect whether the mitochondrial pathway is involved in apoptosis induced by 5 acetamido-1-(methoxybenzyl) isatin, K562 cells $\left(5 \times 10^{4}\right.$ cells per $\mathrm{mL}$ ) were seeded in six-well plates and allowed to grow $2 \mathrm{~h}$, then treated with DMSO or 5-acetamido-1-(methoxybenzyl) isatin $(1 \mu \mathrm{M})$ for $0,6,12,24$ and $48 \mathrm{~h}$ respectively. Washed cells with PBS and stained with $100 \mathrm{nM}$ tetramethylrhodamine methyl ester (TMRM; Invitrogen, USA), then left it in the dark for $15 \mathrm{~min}$ at room temperature. At the end, distinction of mitochondrial membrane potential was analyzed by flow cytometry in the FL-2 channel.

\section{Assessing cell cycle by PI staining}

To determine cell cycle distribution, K562 cells $\left(5 \times 10^{4}\right.$ cells per $\mathrm{mL})$ were exposed to 5-acetamido-1-(methoxybenzyl) isatin (1 $\mu \mathrm{M}$ ) for $0,6,12,24$ and $48 \mathrm{~h}$ respectively. After the treatment, K562 cells were separated by centrifugation and fixed with $1 \mathrm{~mL}$ of $75 \%$ ice-cold ethanol at $-20{ }^{\circ} \mathrm{C}$ overnight. Then, collected the cells and washed them with PBS, incubated with $50 \mu \mathrm{g} \mathrm{mL}$ propidium iodide (PI), $100 \mu \mathrm{g} \mathrm{mL^{-1 }}$ RNase A and $0.2 \%$ Triton $\times$ 100 for $30 \mathrm{~min}$ protected from light at room temperature. A FACS Calibur system (version 2.0, BD) using the CELLQuest program (Becton Dickinson) was used to analyze cell cycle distribution.

\section{Protein extraction and western blot analysis}

Anti-caspase-3, anti-PARP, anti-Bcl-2, anti-Bcl-xl, and anti-Bax were bought from Santa Cruz Biotechnology (Santa Cruz, CA). Other anti-antibodies were obtained from Cell Signaling Technology (CST, Boston, MA). After treatment with DMSO or 5acetamido-1-(methoxybenzyl) isatin for $24 \mathrm{~h}$, cells were collected and lysed in lysis buffer (10 mM Hepes-Na, $150 \mathrm{mM} \mathrm{Na} \mathrm{SO}_{4}$, $1 \mathrm{mM}$ EDTA, 3\% CHAPS, $1 \mathrm{mM}$ phenylmethylsulfonyl fluoride, $10 \mathrm{mg} \mathrm{mL} \mathrm{m}^{-1}$ aprotinin and $10 \mathrm{mg} \mathrm{mL}^{-1}$ leupeptin). The lysates were harvested by centrifuged at $20376 \mathrm{~g}$ at $4{ }^{\circ} \mathrm{C}$ for $10 \mathrm{~min}$. After the determination of protein concentrations of cell lysates, $20 \mu \mathrm{L}$ of each protein sample were taken and added $4 \mu \mathrm{L}$ of $6 \times \mathrm{SB}$ buffer and heated at $100{ }^{\circ} \mathrm{C}$ for $5 \mathrm{~min}$. The samples were separated by SDS-PAGE and electrotransferred to PVDF membranes (Millipore, Bedford, MA). The membranes were probed with the antibodies and incubated with Alexa Fluor ${ }^{\circledR} 680$ Goat Anti-Mouse
IgG and Alexa Fluor® 680 Goat Anti-Rabbit IgG followed by detection using the Odyssey western blotting detection system (Amersham Pharmacia Biotech). ${ }^{24}$

\section{Migration assay}

Wound healing assay - HepG2 cells $\left(5 \times 10^{4}\right.$ cells per $\left.\mathrm{mL}\right)$ were seeded in 6-well plates and incubated for $24 \mathrm{~h}$. Then, the HepG2 cells were scratched with a $10 \mu \mathrm{L}$ pipette tip to form straight lines as wounds. The cells were washed for three times by $1 \times$ PBS and covered with fresh medium with DMSO or 5acetamido-1-(methoxybenzyl) isatin $(0.01 \mu \mathrm{M}, 0.1 \mu \mathrm{M}, 1 \mu \mathrm{M})$ for $0,12,24$, and $48 \mathrm{~h}$ respectively. Then, assay plates were incubated at $37^{\circ} \mathrm{C}$ and $5 \% \mathrm{CO}_{2}$ atmosphere to permit cell migration. Photos were captured by a Nikon Eclipse Ti microscope (Nikon, Tokyo, Japan).

Transwell assay - HepG2 cells were planted in 24-well culture plates containing polycarbonate filter inserts (EMD Millipore corporation, Germany). The HepG2 cells were suspended in Dulbecco's modified Eagle's medium without fetal bovine serum with a density of $5 \times 10^{4}$ cells per $\mathrm{mL}$ and $200 \mu \mathrm{L}\left(2 \times 10^{5}\right.$ cells per well) were added to the upper compartment of the chamber. $600 \mu \mathrm{L}$ Dulbecco's modified Eagle's medium supplemented with $10 \%$ fetal bovine serum was added to the lower chamber. After 30 minutes, the cells were exposed by DMSO or 5-acetamido-1-(methoxybenzyl) isatin $(0.01 \mu \mathrm{M}, 0.1 \mu \mathrm{M}, 1 \mu \mathrm{M})$ and incubated for $24 \mathrm{~h}$ in $5 \% \mathrm{CO}_{2}$ atmosphere at $37^{\circ} \mathrm{C}$ to allow for migration across polycarbonate film. After $24 \mathrm{~h}$, medium in the chamber was removed and the well of the HepG2 cells was washed for three times by $1 \times$ PBS, fixed with methanol and then stained by DAPI. HepG2 cells remaining on the upper side of the filter were then voidede. The photographs of three horizons were taken in random. The migrated HepG2 cells to the lower side of the filter were counted. Finally, the migrated HepG2 cells were observed and photographed by the fluorescence microscope (Nikon, Tokyo, Japan) and five fields of view were record randomly.

\section{Tube forming assay}

The capillary-like network formation of HUVEC cells was investigated with Matrigel-coated 96-well culture plates. Matrigel (13.9 mg mL; BD Bioscience, San Jose, CA, USA) was thawed at $4{ }^{\circ} \mathrm{C}$ and $50 \mu \mathrm{L}$ Matrigel was added to each well of the 24 -well culture plate. Then, the assay plate incubated for 30 minute at $37{ }^{\circ} \mathrm{C}$ for polymerization. The HUVEC cells $\left(1 \times 10^{5}\right.$ cells per well) were suspended in Ham's F-12 medium containing 10\% FBS, and were seeded to the wells. Cells were incubated at $37{ }^{\circ} \mathrm{C}$ in $5 \% \mathrm{CO}_{2}$ for 40 minutes and then treated by DMSO or 5acetamido-1-(methoxybenzyl) isatin (0.01 $\mu \mathrm{M}, 0.1 \mu \mathrm{M}, 1 \mu \mathrm{M})$. After $12 \mathrm{~h}$ of culture, the formation of capillary-like tubes in each well of the culture plate was photographed by a Nikon Eclipse Ti microscope (Nikon, Tokyo, Japan).

\section{Clone formation assay}

The cell cloning rate, that is, the cell seeding survival rate, indicated that the adherent cells survived and the number of colonies formed after the cells were seeded. ${ }^{25}$ Clone formation rate 
reflected two important characteristics of cell proliferation and population dependence. ${ }^{26}$ Therefore, cell clone formation assay can be used to evaluate the ability of compounds to inhibit tumor cell proliferation and population dependence, it can also be used to evaluate the ability of cells to generate tumors in vivo. ${ }^{27}$

HepG2 cells were planted at a density of 1000 cells per $\mathrm{mL}$ in 6-well plates, with $2 \mathrm{~mL}$ of each well. After $24 \mathrm{~h}$ incubation, added $10 \mu \mathrm{L}$ of 5-acetamido-1-(methoxybenzyl) isatin at different concentrations $(0.1 \mu \mathrm{M}, 0.2 \mu \mathrm{M}, 0.4 \mu \mathrm{M}, 0.8 \mu \mathrm{M})$ to each well and set the control group. The culture was terminated on the seventh day after treatment by 5-acetamido-1(methoxybenzyl) isatin. Cell culture supernatant was discarded and cells were washed with PBS. Then, fixed the cells with $1 \mathrm{~mL}$ methanol at room temperature. After fixing cells for $30 \mathrm{~min}, 0.1 \%$ crystal violet was used to stain the cells. Then, supernatant of $0.1 \%$ crystal violet was abandoned and cells were carefully washed with PBS. Three random regions of each well were photographed and the number of clones formed was counted by ImageJ.

\section{Results}

\section{Antiproliferation activities of indole derivatives}

To study the effect of 5-acetamido-1-(methoxybenzyl) isatin on tumor cell proliferation, we selected six tumor cell lines originating from different tissues to perform anti-tumor spectrum testing. As shown in Table 1, 5-acetamido-1-(methoxybenzyl) isatin significantly inhibited the proliferation of human liver cancer HepG2 cells, human colon cancer HT-29 cells, and human prostate cancer PC-3 cells. The highest anti-tumor activity was observed in $\mathrm{K} 562$ cells, with an $\mathrm{IC}_{50}$ of $0.29 \mu \mathrm{M}$. These results indicate that 5 -acetamido-1-(methoxybenzyl) isatin exerted potent anticancer activity against a broad spectrum of cancers.

Next, we tested the toxicity of 5-acetamido-1-(methoxybenzyl) isatin toward normal cells, 5-acetamido-1-(methoxybenzyl) isatin showed lower toxicity than the positive control camptothecin (CPT) (Table 2).

After treatment with 5-acetamido-1-(methoxybenzyl) isatin $(0.1,0.3,1.0$, and $3.0 \mu \mathrm{M})$ for $48 \mathrm{~h}$, $\mathrm{K} 562$ cells continued to grow but the cell growth rate was significantly lower than that in the control group. This result suggested that the inhibitory effect of 5acetamido-1-(methoxybenzyl) isatin on the proliferation of $\mathrm{K562}$ cells was dependent on both time and concentration (Fig. 1A).

\section{Morphological changes in 5-acetamido-1-(methoxybenzyl) isatin-treated $\mathrm{K562}$ cells}

As shown in Fig. 1B, because of treatment by 5-acetamido-1(methoxybenzyl) isatin $(0.1 \mu \mathrm{M})$ for $1,3,6,12,24$ and $48 \mathrm{~h}$, K562 cells presented representative apoptotic morphology (cell shrinkage and/or blebbing). As opposed to DMSO-treated cells, the proportion of elongated cells among $1 \mu \mathrm{M}$ 5-acetamido-1(methoxybenzyl) isatin-treated cells increased as early as $6 \mathrm{~h}$ after treatment, and the changes in cell morphology occurred in a time-dependent manner. Therefore, we conducted further investigation to confirm whether inhibition of K562 cell proliferation was due to the effects of the compound on apoptosis and cell cycle.

\section{5-Acetamido-1-(methoxybenzyl) isatin induced apoptosis in K562 cells}

5-Acetamido-1-(methoxybenzyl) isatin induced apoptosis of K562 cells was quantitatively determined by flow cytometric analysis of

Table 1 Antiproliferation of 5-acetamido-1-(methoxybenzyl) isatin on tumor cell lines in vitro

\begin{tabular}{llc}
\hline & $\mathrm{IC}_{50}(\mu \mathrm{M})$ & \\
\cline { 2 - 3 } Cell line & & $\begin{array}{l}\text { 5-Acetamido-1-(methoxybenzyl) } \\
\text { isatin }\end{array}$ \\
\hline Human leukemia (K562) & $\mathrm{CPT}$ & $0.29 \pm 0.003$ \\
Human prostate cancer (PC-3) & $0.08 \pm 0.004$ & $0.38 \pm 0.06$ \\
Liver cancer (HepG2) & $1.49 \pm 0.08$ & $0.42 \pm 0.08$ \\
Human breast cancer (MCF-7) & $0.07 \pm 0.02$ & $3.37 \pm 0.86$ \\
Non-small cell lung cancer (H460) & $0.37 \pm 0.05$ & $28.40 \pm 14.40$ \\
Human colon cancer (HT-29) & $0.04 \pm 0.002$ & $34.37 \pm 6.30$
\end{tabular}

Table 2 Toxicity of 5-acetamido-1-(methoxybenzyl) isatin on normal cells in vitro

\begin{tabular}{lrr}
\hline & $\mathrm{IC}_{50}(\mu \mathrm{M})$ & \\
\cline { 2 - 3 } Cell line & & $\begin{array}{c}\text { 5-Acetamido-1-(methoxybenzyl) } \\
\text { isatin }\end{array}$ \\
\hline Human hepatic stellate (L02) & $\mathrm{CPT}$ & $5.12 \pm 0.64$ \\
Human umbilical vein endothelial (HUVEC) & $0.01 \pm 0.002$ & $8.22 \pm 1.36$ \\
Human embryonic kidney (HEK-293) & $0.25 \pm 0.03$ & $17.56 \pm 5.07$
\end{tabular}


cells double-labeled with Annexin V-FITC and PI. After treatment with $1 \mu \mathrm{M}$ 5-acetamido-1-(methoxybenzyl) isatin for 6, 12, 24 and $48 \mathrm{~h}$, significant apoptosis and increased number of apoptotic K562 cells were observed compared with those in control (Fig. 2A). The total apoptosis rate in K562 cells treated with $1 \mu \mathrm{M}$ 5-acetamido-1-(methoxybenzyl) isatin for $48 \mathrm{~h}$ reached $51.1 \%$ (compared with $5.1 \%$ in control). Thus, we can conclude that 1 $\mu \mathrm{M}$ 5-acetamido-1-(methoxybenzyl) isatin inhibits $\mathrm{K} 562$ cell proliferation by inducing the apoptotic pathway and the apoptosis rate increased in a time-dependent manner.

To further study the effect of 5-acetamido-1-(methoxybenzyl) isatin on K562 apoptosis and the molecular mechanism of apoptosis induction, changes in the expression of apoptosisrelated proteins were investigated. After treatment of $\mathrm{K} 562$ cells with 1, 3 and $10 \mu \mathrm{M}$ 5-acetamido-1-(methoxybenzyl) isatin for $24 \mathrm{~h}$, total cellular protein was extracted.

As shown in Fig. 2C, compared with that in control, Caspase-3 activation increased gradually as the concentration of 5acetamido-1-(methoxybenzyl) isatin increased, $89 \mathrm{kDa}$ and 24 $\mathrm{kDa}$ fragmentation products likely resulted from PARP cleavage induced by the activated Caspase 3. Furthermore, 5-acetamido-1(methoxybenzyl) isatin activated PARP in a concentrationdependent manner. These results demonstrate that 5acetamido-1-(methoxybenzyl) isatin induced Caspase- 3 activation and modulated the expression of apoptosis-related proteins, thereby indicating that 5-acetamido-1-(methoxybenzyl) isatin induced apoptosis in K562 cells.

\section{Mitochondrial membrane potential measurement}

Mitochondria play a significant role in the apoptotic pathway in various cancer cell lines. ${ }^{28}$ To examine mitochondrial involvement in 5-acetamido-1-(methoxybenzyl) isatin-induced apoptosis, K562 cells were treated with DMSO or 5-acetamido-1-

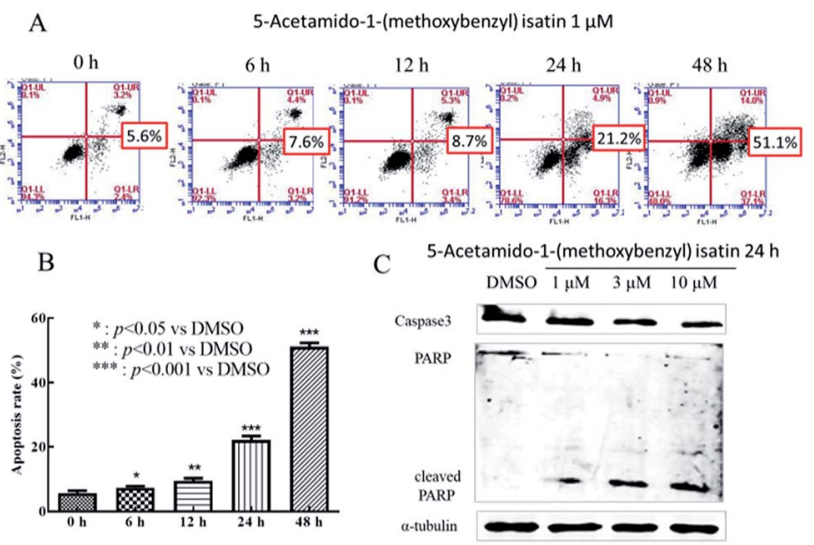

Fig. 2 5-Acetamido-1-(methoxybenzyl) isatin induced apoptosis in K562 cells. (A) Flow cytometric histograms. K562 cells were treated with $1 \mu$ M 5-acetamido-1-(methoxybenzyl) isatin for $0,6,12,24,48 \mathrm{~h}$ and were labeled with Annexin V-FITC and PI. (B) Columns show mean values of three experiments $( \pm S D)$. (C) The effect of 5-acetamido-1(methoxybenzyl) isatin on the expression of caspase-3, PARP, and the cleavage of substrate PARP proteins. K562 cells were treated with 5acetamido-1-(methoxybenzyl) isatin at 1, 3, $10 \mu \mathrm{M}$ for 24 h. $\alpha$-Tubulin was used as an equal loading control. (methoxybenzyl) isatin $(1 \mu \mathrm{M})$ for $0,6,12,24$ and $48 \mathrm{~h}$ respectively, then stained with TMRM.

Changes in the mitochondrial membrane potential of $\mathrm{K} 562$ cells are shown in Fig. 3A, with a significant decline in mitochondrial membrane potential from $96.9 \%$ to $93.5 \%$ at $6 \mathrm{~h}$, to $94.3 \%$ at $12 \mathrm{~h}$, to $80 \%$ at $24 \mathrm{~h}$ and to $48 \%$ at $48 \mathrm{~h}$. These results indicated that 5-acetamido-1-(methoxybenzyl) isatin can cause a decrease in the mitochondrial membrane potential, which may induce apoptosis in K562 cells through the mitochondrial pathway.

Expression of apoptotic mitochondrial pathway-associated proteins was further detected by western blotting. As shown in Fig. 3C, unlike in the control group, the expression of the anti-apoptotic proteins Bcl-2 and Bcl-xl was down-regulated, whereas the expression of the pro-apoptotic protein Bax was up-regulated following 5-acetamido-1-(methoxybenzyl) isatin treatment in a concentration-dependent manner. As shown in Fig. 3B, as the concentration of 5-acetamido-1-(methoxybenzyl) isatin increased, the $\mathrm{Bcl}-2 / \mathrm{Bax}$ expression ratio decreased. These results suggested that these three proteins associated with mitochondrial apoptosis pathways (Bcl-2, Bcl-xl, and Bax) are involved in the cell apoptosis process in 5-acetamido-1(methoxybenzyl) isatin-treated $\mathrm{K} 562$ cells, indicating that 5acetamido-1-(methoxybenzyl) isatin induces apoptosis in $\mathrm{K} 562$ cells through the mitochondrial apoptosis pathway.

\section{5-Acetamido-1-(methoxybenzyl) isatin induced $G_{2} / M$ cell cycle phase arrest in $K 562$ cells}

DNA content was measured by flow cytometry to evaluate the cell cycle distribution of K562 cells with or without 5-acetamido1-(methoxybenzyl) isatin $(1 \mu \mathrm{M})$ treatment. As shown in Fig. $4 \mathrm{~A}$, after exposure to 5-acetamido-1-(methoxybenzyl) isatin for 1, 3,

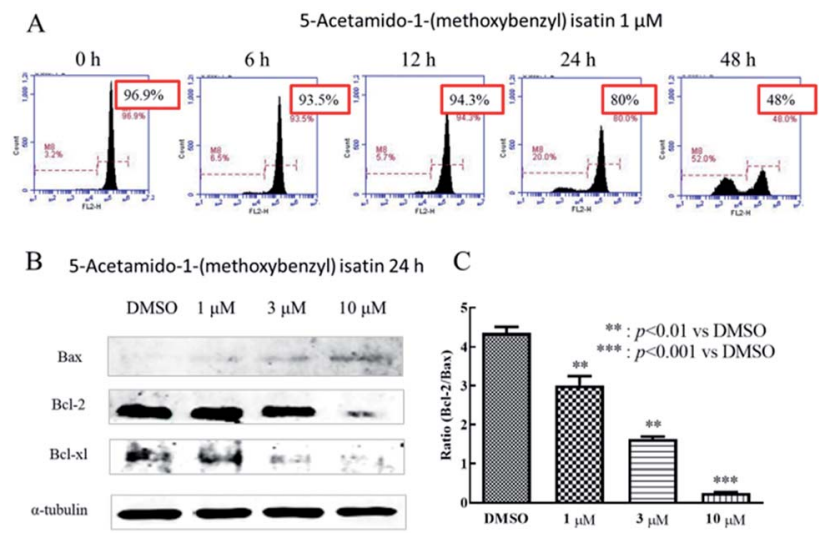

Fig. 3 Mitochondrial membrane potential of $\mathrm{K} 562$ cells after treatment with 5-acetamido-1-(methoxybenzyl) isatin. (A) K562 cells were treated with DMSO or 5-acetamido-1-(methoxybenzyl) isatin ( $1 \mu \mathrm{M})$ for $0,6,12,24$, and $48 \mathrm{~h}$, respectively, and then stained with $100 \mathrm{nM}$ TMRM and analyzed by flow cytometry. (B) Western blot analysis of $\mathrm{Bax}, \mathrm{Bcl}-2$, and $\mathrm{BCl}-\mathrm{xl}$ proteins: $\mathrm{K} 562$ cells were treated with 5 -acetamido-1-(methoxybenzyl) isatin at 1,3 , and $10 \mu \mathrm{M}$ for $24 \mathrm{~h}$, and $\alpha$ tubulin was used as an equal loading control. (C) The effect of 5acetamido-1-(methoxybenzyl) isatin on apoptosis-related proteins in K562 cells. 


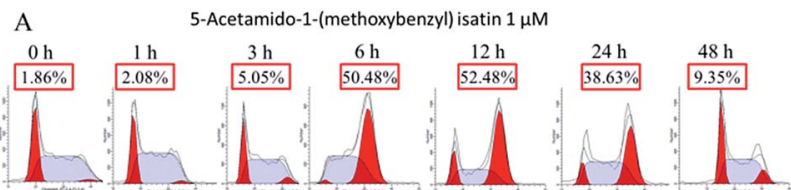

B

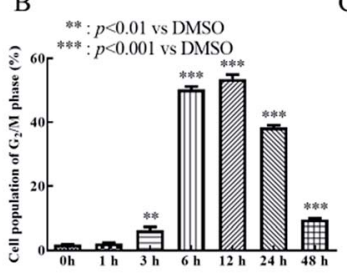

5-Acetamido-1-(methoxybenzyl) isatin $24 \mathrm{~h}$

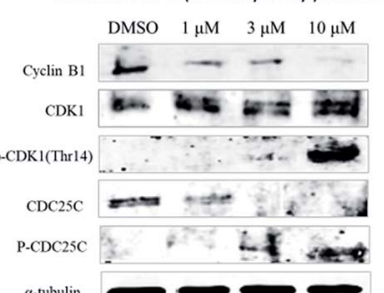

Fig. 4 Effect of 5-acetamido-1-(methoxybenzyl) isatin on cell cycle of K562 cells. (A) K562 cells were treated with 5-acetamido-1-(methoxybenzyl) isatin $(1 \mu \mathrm{M})$ for $0,1,3,6,12,24$, and $48 \mathrm{~h}$, respectively and then stained with $\mathrm{PI}$ and analyzed by flow cytometry. (B) Bars show mean values of three experiments $( \pm S D)$. (C) 5-Acetamido-1(methoxybenzyl) isatin $(1,3$, and $10 \mu \mathrm{M})$ gradually decreased the expression of Cyclin B and CDC25C, while gradually increasing the expression of $\mathrm{p}-\mathrm{CDK} 1$ (Thr14) and $\mathrm{p}-\mathrm{CDC} 25 \mathrm{C}$

$6,12,24$ and $48 \mathrm{~h}$, the percentage of $\mathrm{K} 562$ cells in the $\mathrm{G}_{2} / \mathrm{M}$ phase continued to increase. At the outset, only $1.86 \%$ cells were in the $\mathrm{G}_{2} / \mathrm{M}$ phase, but as the treatment time increased, the proportion of cells in the $\mathrm{G}_{2} / \mathrm{M}$ phase increased gradually until $12 \mathrm{~h}$, when the $\mathrm{G}_{2} / \mathrm{M}$ phase cell proportion peaked at $52.48 \%$. These results indicate that 5-acetamido-1-(methoxybenzyl) isatin possesses cell proliferation inhibitory activity and can induce cell cycle arrest of $\mathrm{K} 562$ cells in the $\mathrm{G}_{2} / \mathrm{M}$ phase.

The expression of cell cycle-related proteins was analyzed by western blotting. The results are shown in Fig. 4C. After $24 \mathrm{~h}$ treatment with 5-acetamido-1-(methoxybenzyl) isatin, the total CDK1 expression in cells did not change significantly despite an increase in the compound concentration, but the expression of Cyclin B and CDC25C gradually decreased. Simultaneously, the expression of p-CDK1 (Thr14) and p-CDC25C increased gradually. Their protein levels were significantly different from those in the negative control group. These results indicate that 5acetamido-1-(methoxybenzyl) isatin affects the expression of Cyclin B, p-CDC25C, p-CDK1 (Thr14), and CDC25C, and arrests $\mathrm{K} 562$ cells in the $\mathrm{G}_{2} / \mathrm{M}$ phase.

\section{5-Acetamido-1-(methoxybenzyl) isatin inhibits HepG2 cell migration and chemotaxis}

5-Acetamido-1-(methoxybenzyl) isatin exerted significant effects on the proliferation of HepG2 cells and exhibited antitumor activity at $0.42 \mu \mathrm{M}$ after $48 \mathrm{~h}$ treatment. In order to further evaluate the diversity of the anti-tumor activity by 5 -acetamido1-(methoxybenzyl) isatin, the migration and chemotaxis ability of HepG2 cells was examined using wound healing and transwell assays.

After HepG2 cells were wounded, they were treated with 5acetamido-1-(methoxybenzyl) isatin $(0.01,0.1$, and $1 \mu \mathrm{M})$ for 0 , 12, 24, and 48 h respectively. As shown in Fig. 5, 5-acetamido-1(methoxybenzyl) isatin significantly inhibited the lateral

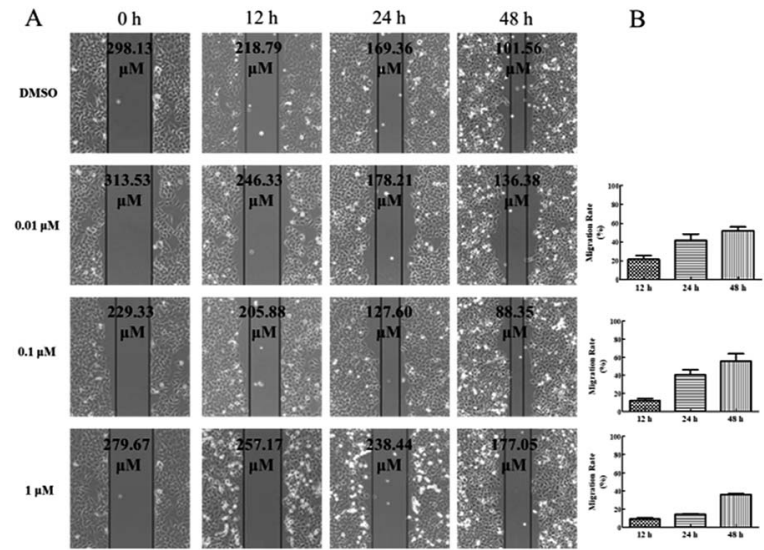

Fig. 5 Effect of 5-acetamido-1-(methoxybenzyl) isatin on HepG2 cell migration assessed using a wound healing assay. (A) HepG2 cells were wounded and then treated with 5-acetamido-1-(methoxybenzyl) isatin $(0.01,0.1$, and $1 \mu \mathrm{M})$ for $0,12,24$, and $48 \mathrm{~h}$ respectively. Lateral migration and repair of HepG2 cells within a certain concentration range significantly inhibited by 5-acetamido-1-(methoxybenzyl) isatin. (B) Bars show mean values of three experiments ( $\pm S D$ ).

migration and repair of HepG2 cells within a certain concentration range. As shown in Fig. 6, 5-acetamido-1(methoxybenzyl) isatin $(0.01,0.1$, and $1 \mu \mathrm{M})$ also markedly inhibited the migration of HepG2 cells, with similar potency as that demonstrated in the wound healing assay.

\section{5-Acetamido-1-(methoxybenzyl) isatin suppresses tube formation in HUVECs}

HUVECs were stimulated with several concentrations of 5acetamido-1-(methoxybenzyl) isatin $(0.01,0.1$ and $1 \mu \mathrm{M})$ for $12 \mathrm{~h}$. Angiogenesis of the cells was observed under an inverted microscope to evaluate the effect of 5-acetamido-1-
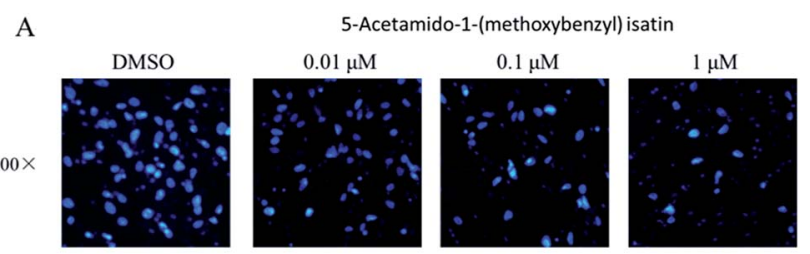

B

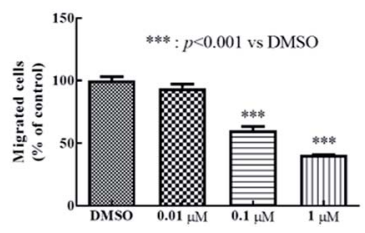

Fig. 6 Effect of 5-acetamido-1-(methoxybenzyl) isatin on HepG2 cell migration assessed using the transwell assay. (A) HepG2 cells were treated with DMSO or 5-acetamido-1-(methoxybenzyl) isatin (0.01, 0.1 , and $1 \mu \mathrm{M}$ ). After $24 \mathrm{~h}$, medium was removed, and the cells were fixed with methanol and then stained with DAPI. HepG2 cells remaining on the upper side of the filter were then voided. The photographs of three horizons were captured in random. (B) Bars show mean values of three experiments on cells treated with 5acetamido-1-(methoxybenzyl) isatin ( $(\mathrm{SD})$. 
(methoxybenzyl) isatin. As shown in Fig. 7, DMSO did not affect tube formation by HUVECs, whereas 5-acetamido-1(methoxybenzyl) isatin inhibited the angiogenesis in a dosedependent manner.

\section{5-Acetamido-1-(methoxybenzyl) isatin inhibits colony formation of HepG2 cells}

After treatment with $0.1,0.2,0.4$, and $0.8 \mu \mathrm{M}$ of 5 -acetamido-1(methoxybenzyl) isatin for 7 days, we observed (Fig. 8A) that as the concentration of the 5-acetamido-1-(methoxybenzyl) isatin increased, the number of colonies formed by HepG2 cells decreased significantly. We then used ImageJ to calculate the number of clones formed. As shown in Fig. 8B, the higher the compound concentration, the lower was the number of clones formed. The results indicate that 5-acetamido-1(methoxybenzyl) isatin inhibits tumor cell proliferation and population dependence in a concentration-dependent manner.

\section{Discussion}

Cancer is one of the most serious diseases and the number of cancer patients continues to increase rapidly. The adverse reactions and resistance of existing drugs have resulted in a necessity for novel drugs against cancer. In addition to surgery and radiation therapy, developing targeted anti-tumor drugs will be a far-researching milestone.

Some studies indicate that the use of oxindole as a lead compound to synthesize and screen anti-tumor drugs with novel structure, stronger targeting, and stronger selectivity has broad research prospects. In 2010, Tang Peng Cho synthesized a series of potent vascular inhibitors by introducing a pyrrole-cyclocaprolactam structure at the 3-position of indole. Among these, two compounds showed good pharmacokinetics and significant effects on human colon cancer

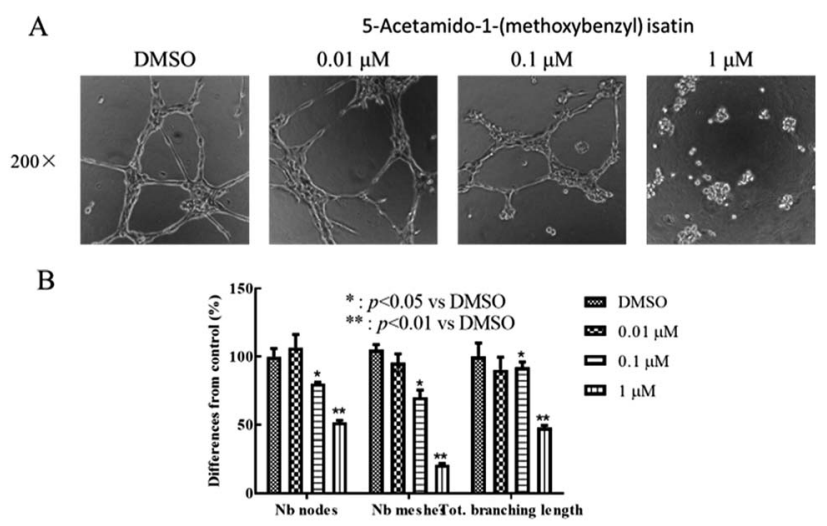

Fig. 7 Suppressive effects of different concentrations of 5-acetamido-1-(methoxybenzyl) isatin on tube formation of HUVECs. (A) HUVECs cultured on matrigel-coated plates were treated with the indicated concentrations of 5-acetamido-1-(methoxybenzyl) isatin $(0.01,0.1$, and $1 \mu \mathrm{M})$ for $12 \mathrm{~h}$. Tube formation was observed by microscopy, and representative images are shown. (B) Bars show mean values of three experiments on 5-acetamido-1-(methoxybenzyl) isatin-treated HUVECs compared with the control $( \pm S D)$.

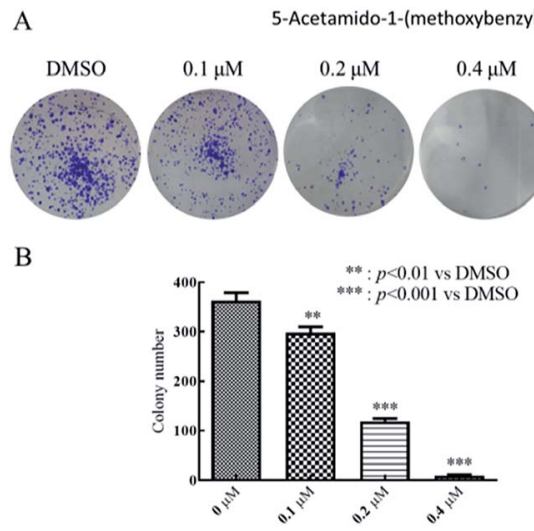

Fig. 8 Effect of 5-acetamido-1-(methoxybenzyl) isatin on colony formation by HepG2 cells. (A) HepG2 cells were treated with $0.1,0.2$, 0.4 , and $0.8 \mu \mathrm{M} 5$-acetamido-1-(methoxybenzyl) isatin for 7 days and photographed. As the concentration of 5-acetamido-1-(methoxybenzyl) isatin increased, the number of colonies formed by HepG2 cells decreased significantly. (B) 5-Acetamido-1-(methoxybenzyl) isatin inhibited tumor cell proliferation and population dependence in a concentration-dependent manner. ImageJ was used to calculate the number of clones formed.

HT-29 cells transplanted in nude mice. ${ }^{29}$ In 2012, Azizian Javad synthesized a series of compounds using isatin as a starting material, and tested three human cancer cell lines to screen a highly active compound based on cytotoxicity. Formation of a lipid-soluble ring containing a hydrogen bond between the receptor and the 3-position of indole appears to be an important reason for this series of compounds to be effective VEGFR-2 inhibitors. ${ }^{30}$ In 2014 , $\mathrm{Z}$ Ma found that the endogenous oxindole isatin could induce apoptosis in the human breast cancer cell line, MCF7, through the mitochondrial pathway, with a significant decrease in the expression of Bcl-2 and Bcl-2/Bax in cells. ${ }^{20}$

Our previous studies have revealed that 5-acetamido-1(methoxybenzyl) isatin possesses excellent cytotoxic activity against $\mathrm{K} 562$ cells $\left(\mathrm{IC}_{50}=0.29 \mu \mathrm{M}\right)$. In addition, it also revealed inhibition of HepG2 cells, HT-29 cells and PC-3 cells to some extent (Table 2). These findings indicate that 5-acetamido-1(methoxybenzyl) isatin possesses superior and broad-spectrum anticancer action against various cancers. Moreover, 5acetamido-1-(methoxybenzyl) isatin showed lower toxicity toward normal cells than CPT. Morphological analysis indicats that 5-acetamido-1-(methoxybenzyl) isatin acted by inducing apoptosis and causing cell cycle arrest. Typical apoptotic morphology occurred in K562 cells after the treatment with 5acetamido-1-(methoxybenzyl) isatin. ${ }^{31}$

Mitochondrial dysfunction often triggers some cellular signaling to induce apoptosis. ${ }^{32}$ Flow cytometry analysis showed that exposure to 5-acetamido-1-(methoxybenzyl) isatin significantly induced apoptosis in $\mathrm{K} 562$ cells, as the result of mitochondrial membrane potential collapsion. Simultaneously, 5-acetamido-1-(methoxybenzyl) isatin induced Caspase- 3 activation and cleavage of its substrate PARP. After treatment with 5-acetamido-1-(methoxybenzyl) isatin, Bax was 
up-regulated but Bcl-2 and Bcl-xl were down-regulated. These findings indicate that 5-acetamido-1-(methoxybenzyl) isatin induced mitochondrial pathway-mediated apoptosis in $\mathrm{K} 562$ cells.

The cellular DNA content was measured by flow cytometry to evaluate the cell cycle distribution of K562 cells. 5-Acetamido-1(methoxybenzyl) isatin induced cell cycle arrest of K562 cells in the $\mathrm{G}_{2} / \mathrm{M}$ phase by $12 \mathrm{~h}$ of treatment. Cell cycle-related protein indicated that the expression of p-CDK1 (Thr14) and p-CDC25C increased gradually, compared with negative control group. These results indicate that 5 -acetamido-1-(methoxybenzyl) isatin could arrest the $\mathrm{K} 562$ cells in the $\mathrm{G}_{2} / \mathrm{M}$ phase by affecting the expression of cycle-related proteins.

Beyond proliferation, cell migration, directional chemotaxis, and complex tube formation are all critical, distinct, and functional components of tumor-associated angiogenesis. Wound healing and transwell experiments showed that inhibition ability of wound repairment, chemotaxis, and migration of HepG2 cells was depended on the concentration of 5acetamido-1-(methoxybenzyl) isatin. Cell tube formation assay revealed that 5-acetamido-1-(methoxybenzyl) isatin could dosedependently inhibit the angiogenesis of HUVECs.

Furthermore, clone formation assay expressed that 5acetamido-1-(methoxybenzyl) isatin inhibited tumor cell proliferation and population dependence in a concentrationdependent manner.

These data support the potential application of 5acetamido-1-(methoxybenzyl) isatin as a chemotherapeutic agent against human leukemia and human liver cancer. However, other pivotal signaling pathways induced by 5acetamido-1-(methoxybenzyl) isatin and its antitumor pharmacological activity in vivo need to be examined in future studies.

\section{Conclusions}

The present study revealed that 5-acetamido-1-(methoxybenzyl) isatin induces apoptosis in K562 cells via the mitochondrial pathway and arrests cells in the $\mathrm{G}_{2} / \mathrm{M}$ phase by down-regulating Cyclin B and CDC25C and up-regulating p-CDC25C and p-CDK1 (Thr14). Findings on the effect of the indole derivative 5acetamido-1-(methoxybenzyl) isatin on the migration, angiogenesis, and clone formation of cancer cells also provide a strong foundation for further studies on the antitumor activity and mechanism of action of indole compounds.

In sum up, malignant tumors seriously influence human health and put pressure on life, targeted drugs can reduce the mortality of cancer patients, and the space for demand is huge. Fortunately, the present findings prove that 5-acetamido-1(methoxybenzyl) isatin exerts an anticancer effect in vitro. There is no doubt that in vivo research is essential, so we are preparing for further research.

\section{Conflicts of interest}

The authors declare that there are no conflicts of interest.

\section{Acknowledgements}

This work was supported jointly by "Young and middle-aged backbone innovative talents training plan" of Tianjin universities, International Science \& Technology Cooperation Program of China (2013DFA31160). We would like to thank Editage for English language editing.

\section{References}

1 W. Chen, R. Zheng, P. D. Baade, S. Zhang, H. Zeng, F. Bray, A. Jemal, X. Q. Yu and J. He, Ca-Cancer J. Clin., 2016, 66, 115-132.

2 F. Bray, J. Ferlay, I. Soerjomataram, R. L. Siegel, L. A. Torre and A. Jemal, Ca-Cancer J. Clin., 2018, 68, 394-424.

3 Q. Zhang, Y. Teng, Y. Yuan, T. Ruan, Q. Wang, X. Gao, Y. Zhou, K. Han, P. Yu and K. Lu, Eur. J. Med. Chem., 2018, 156, 800-814.

4 A. K. Rathi, R. Syed, V. Singh, H. S. Shin and R. V. Patel, Recent Pat. Anti-Cancer Drug Discovery, 2017, 12, 55-72.

5 C. F. Liu, H. J. Zhang and Z. S. Quan, Lett. Drug Des. Discovery, 2016, 13, 833-839.

6 M. Aman and R. V. Ravishankar, Biocontrol Sci. Technol., 2016, 26, 476-491.

7 S. Wang, Y. Chen, X. Liu, X. Xu, X. Liu, B. F. Liu and G. Zhang, Arch. Pharm., 2014, 347, 32-41.

8 P. Ashok, C. L. Lu, S. Chander, Y. T. Zheng and S. Murugesan, Chem. Biol. Drug Des., 2015, 85, 722-728.

9 M. Kale, A. Narute and T. Kalyankar, Clin. Anti-Inflammatory Anti-Allergy Drugs, 2014, 1, 39-44.

10 R. J. Motzer, B. Escudier, A. Gannon and R. A. Figlin, Oncologist, 2017, 22, 41-52.

11 A. P. Zhou, Y. Bai, Y. Song, H. Luo, X. B. Ren, X. Wang, B. Shi, C. Fu, Y. Cheng, J. Liu, S. Qin, J. Li, H. Li, X. Bai, D. Ye, J. Wang and J. Ma, Oncologist, 2019, 24, e702-e708.

12 P. Yu, F. X. Liu, H. Sun, Preparation of 1,3-substituted-5acetamidoindolinone compounds as antitumor drugs, China, CN103554008A, 2014-02-05.

13 K. Tong, C. Xin and W. Chen, Oncol. Lett., 2016, 13, 518.

14 P. K. Raghav, R. Kumar, V. Kumar and G. Raghava, Mol. Genet. Genomic Med, 2019, e910.

15 Y. Yan, R. Xie, Q. Zhang, X. Zhu, J. Han and R. Xia, Platelets, 2019, 30, 75-80.

16 C. T. Peng, D. S. Yi, J. Feng, H. F. Jian, L. Y. Jiang, L. Xiao, H. P. Jiang, L. L. Ya, L. Zhang and B. Hu, J. Med. Chem., 2010, 53, 8140.

17 B. Liu, Y. Liu, Y. Wang, C. Xie, M. Gan, T. Han, J. Cao and J. Wang, Pathol., Res. Pract., 2019, 215, 152592.

18 J. C. Xu, X. P. Zhou, X. A. Wang, M. D. Xu, T. Chen, T. Y. Chen, P. H. Zhou and Y. Q. Zhang, J. Cancer, 2019, 10, 2415-2424.

19 L. G. Rodriguez, X. Wu and J. L. Guan, Methods Mol. Biol., 2005, 294, 23-29.

20 Z. Ma, L. Hou, Y. Jiang, Y. Chen and J. Song, Oncol. Rep., 2014, 32, 2111-2117.

21 X. Chang, X. Zhao, J. Wang, S. Ding, L. Xiao, E. Zhao and X. Zheng, Adv. Anticancer Agents Med. Chem., 2019, DOI: 10.2174/1871520619666191023094610. 
22 T. Nomura, K. Hirata, T. Shimaoka, M. Yamakawa, N. Koizumi, R. Suzuki, K. Maruyama and N. Utoguchi, Biol. Pharm. Bull., 2017, 40, 1661-1668.

23 S. Hua, Y. Zhang, P. Wang, W. Dong, Z. Qian, Y. Yuan and Y. Teng, J. Tianjin Univ. Sci. Technol., 2014, 24, 591-594.

24 Y. Teng, L. Wang, H. Liu, Y. Yuan, Q. Zhang, M. Wu, L. Wang, H. Wang, Z. Liu and P. Yu, Chem.-Biol. Interact., 2017, 261, 103-107.

25 C. M. Yeh, J. Shay, T. C. Zeng, J. L. Chou, T. H. Huang, H. C. Lai and M. W. Chan, Int. J. Oncol., 2014, 45, 2101-2107. 26 Z. Wang, Y. I. Gao, Y. Liu, J. Chen, J. Wang, S. Gan, X. U. Danfeng and X. Cui, Int. J. Mol. Med., 2015, 36, 931-938.

27 C. P. Cheng, L. C. Huang, Y. L. Chang, C. H. Hsieh, S. M. Huang and D. Y. Hueng, OncoTargets Ther., 2016, 7, 41460-41472.
28 K. Tong, C. Xin and W. Chen, Oncol. Lett., 2016, 13, 518.

29 T. P. Cho, S. Y. Dong, F. Jun, F. J. Hong, Y. J. Liang, X. Lu, P. J. Hua, L. Y. Li, Z. Lei and H. Bing, J. Med. Chem., 2010, 53, 8140.

30 J. Azizian, K. M. Mohammadi, O. Firuzi, N. Razzaghiasl and R. Miri, Med. Chem. Res., 2011, 21, 3730-3740.

31 B. Choudhury, R. Kandimalla, R. Bharali, J. Monisha, A. B. Kunnumakara, K. Kalita and J. Kotoky, Front. Pharmacol., 2016, 7, 3.

32 P. L. Ong, B. C. Weng, F. J. Lu, M. L. Lin, T. T. Chang, R. P. Hung and C. H. Chen, Food Chem. Toxicol., 2008, 46, 1535-1547. 